International Research Journal of Management, IT \& Social Sciences
Available online at https://sloap.org/journals/index.php/irjmis/
Vol. 6 No. 5, September 2019, pages: 89 94
ISSN: 2395-7492
https://doi.org/10.21744/irjmis.v6n5.702

\title{
Effect of Job Attitude, Subjective Norm and Perceived Behavior Control on Employee Intention to Quit
}

Ida Ayu Gita Dwi Sasmita ${ }^{a}$ Putu Saroyeni Piartrini ${ }^{\text {b }}$

\section{Article history:}

Received: 09 March 2019

Accepted: 31 May 2019

Published: 22 August 2019

\section{Keywords:}

intention;

job attitude;

perceived behavior control;

quit;

subjective norms;

\begin{abstract}
Termination of employees from the company is preceded by an employee intention to quit. Job attitude is one of the factors that explain the intention or perception adopted by someone both positive and negative towards employee behavior. Subjective norms are people's perceptions. Perceived behavioral control is a belief in the capabilities and resources they have so they feel they have the opportunity to work elsewhere. The purpose of this study is to determine the effect of Attitude on Work, Subjective Norms, and Perceived Behavior Control on Intention to Quit. This study used 85 permanent employees at Asana Agung Putra Bali Hotel as respondents with data analysis techniques using multiple linear regression analysis techniques. The results showed that Job attitude had a significant positive effect on the intention to quit, subjective norms had a significant positive effect on the intention to quit, and perceived behavior control had a significant positive effect on the intention to quit.
\end{abstract}

2395-7492@ Copyright 2019. The Author. This is an open-access article under the CC BY-SA license (https://creativecommons.org/licenses/by-sa/4.0/) All rights reserved.

\section{Author correspondence:}

Ida Ayu Gita Dwi Sasmita,

Faculty Economic and Business Udayana University, Denpasar, Indonesia.

Email address: gitasasmita88@yahoo.com

\section{Introduction}

The high turnover rate at the Asana Agung Putra Bali Hotel, means that employee turnover is more frequent. Of course, this will be detrimental to the Hotel, because if an employee leaves the company, the Hotel must incur more costs starting from the advertising process, selection, training, to the process of employee placement. In addition, the selection process does not mean the development of the company increases so that it requires additional new employees, but because there are employees who leave the company, so the personnel or HRD is often preoccupied with the selection process of new employees. HRD sometimes is not able to prepare at any time for replacement employees who leave, because employees who leave are unpredictable from the start.

a Udayana University, Denpasar, Indonesia

${ }^{\mathrm{b}}$ Udayana University, Denpasar, Indonesia 
In fact, many employees remain in the hotel where they work by accepting the conditions of work as is and there are also employees who have the intention to leave. The results of interviews with 5 employees who are still working at Asana Agung Putra Bali Hotel, namely from the Front Office, Marketing, House Keeping, Accounting, and Food and Beverage Product divisions.

According to Mangkuprawira \& Hubeis (2007); Martini et al., (2018); Yunita et al., (2019), Intention to quit occurs through a psychological process where employees feel a decrease in the level of job satisfaction, then low job satisfaction will affect the decrease in motivation characterized by stress, physical pain, laziness to work, decreased work quality, personal communication diminished, indifference attitudes towards work duties, the next employee will decide to think and intend to go out to find alternative work, the employee then compares alternative work with his current job and makes a decision to stay or leave the company, at the last stage is action that employees take to stay or leave the organization.

The intention is a factor that was investigated in-depth in previous studies. Intention is the main cause in explaining employees' intention to leave. Theory of planned behavior provides a theoretical framework that is very useful for predicting employees' intention to leave because the concept of intention is related to an individual's willingness or their effort to do something in a certain way. This research is a quantitative study in which systematic research on parts and phenomena as well as their relationships, the factors that affect employee's intention to quit are attitudes toward work. Job attitudes one of the factors that explain the intention or perception adopted by someone both positive and negative towards employee behavior. Attitude is a psychological tendency expressed by evaluating certain entities with various sizes, both likes, and dislikes (Ajzen \& Fishbein, 1980). Kim et al., (2003), found that employees' intention to leave was affected by attitudes, where service sector employees quit their jobs usually as a result of unsatisfactory situations such as low motivation, low salary, and poor service conditions. According to Appollis (2010), employee attitudes toward work show job satisfaction in the company affect the intention to quit the job, because if employees feel satisfied at work, then the intention to stop working employees will be low. Williams (2000), states that employees who have a less satisfied attitude, are less motivated and have the perception of available job opportunities as an alternative then they have more intention to quit their jobs.

Factors other than attitudes toward work, subjective norms also affect employees' intention to quit. Subjective norms are one of the important latent variables in the theory of planned behavior. This variable defines the perception of others such as friends and family, the belief that a person should or should not take certain actions. Tan \& Thomson (2000), suggested that subjective norms (subjective norms) are the social effect someone to behave. Someone will have a desire for an object or behavior if he is affected by people around him to do it or he believes that the environment or the people around him support what he does. Thus, this variable can also be explained as social pressures on actions or behavior by someone. Brouwer et al., (2009), suggested that individuals tend to act and perform suggested behaviors as expected by family, friends and direct superiors. For example, an injured employee can extend a period of time off because his family wants him to have to rest at home and also an employee who feels pressured by the employer will have the intention to leave because his family wants him to find a better job. According to Dominguez et al., (2018), those social factors are involved in an individual intending to leave his job. Jehanzeb et al., (2013), stated the views and thoughts of others that are significant (such as family, friends, colleagues and direct superiors) towards a suggested behavior that will put pressure on individuals, for example in terms of stopping work.

\section{Hypothesis}

H1: Job attitude has a positive and significant effect on the intention to quit.

H2: Subjective norms have a positive and significant effect on the intention to quit.

H3: Perceived Behavior Control has a positive and significant effect on the intention to quit.

\section{Materials and Methods}

The population in this study consisted of 85 permanent employees. Data collection techniques used in this study were interviews and questionnaires. This study uses multiple regression analysis methods to determine the effect of independent variables on the dependent variable. 


\section{Results and Discussions}

The significance value of 0,000 which is smaller than the value of $\alpha=0.05$, then the multiple linear regression model is feasible as an analysis tool to test the effect of independent variables on the dependent variable. The significance value of the t-test is 0.002 . The results of the analysis of the effect of attitudes on work towards the intention to quit obtained Sig. $t$ of 0.002 with a beta coefficient of 0.466 . Sig. Value $t 0.002<0.05$ indicates that $\mathrm{H} 0$ is rejected and $\mathrm{H} 1$ is accepted. This result means that attitude towards work has a positive and significant effect on the intention to quit. The results showed that the attitude variable towards work had a positive and significant effect on the intention to quit. This can be seen from individuals willing to accept the tasks given by superiors and the ability of individuals to complete the work given by superiors and the individual is able to make decisions in work.

Research from Mobley (1986), also suggests that every individual who enters a work organization carries a number of expectations within himself, for example, the work itself, the social environment and his development, not unlike the research by Ologunde et al., (2006), where service sector employees leave from their work usually as a result of unsatisfactory situations such as undeveloped employees in careers and the attitude of the leader in directing employees to work. Harbinson (1973), also revealed an employee's decision to continue with his current company or to look for opportunities elsewhere depending on factors such as working conditions, job satisfaction.

Williams (2000), states that employees who have a less satisfying attitude and have the perception of the availability of job opportunities as an alternative then they have more intention to quit their jobs. In line with Schalk \& Van Rijckevorsel (2007), personal characteristics and attitudes at work are positively and significantly related to intention to leave the company. This is similar to the research of Kim et al., (2003), who found that employee exit intentions were positively affected by attitude, not different from Trevor (2011), research which suggested that employee attitudes toward work were more likely to lead to intention to leave work for individuals with higher work abilities and those who had experience in specific job training.

Research according to Judge \& Mueller (2012) which states that if negative employee attitudes toward work, then negative behavior in the workplace will increase, such as absenteeism, intention to quit the company until finally the decision to quit the company. In line with research Clark et al., (2009), suggested that the attitude of employee dissatisfaction which will reduce employee performance and will cause the intention to stop working.

The involvement of superiors in providing assistance in work affects the intention of individuals out of the company, this is in line with research Kurniati et al., (2007); Korry et al., (2017); Kusumanegara et al., (2018), which states that the leaders of an organization are expected to be able to listen and assess the thoughts of their subordinates and accept the contribution of their thoughts, as long as these thoughts can be implemented. Most leaders issue commands more often and explains what needs to be done, this makes employees passive and does not dare to give new ideas out of fear. This affects individuals who have the intention to leave a high job such as looking for information on employment opportunities in a company that is better than before.

The significance value of the t-test is 0.042 . The results of the analysis of the effect of subjective norms on the intention to quit obtained Sig. $t$ of 0.042 with a beta coefficient of 0.104 . Sig. Value t $0.042<0.05$ indicates that H0 is rejected and $\mathrm{H} 1$ is accepted. This result means that subjective norms have a positive and significant effect on the intention to quit.

The results showed that the subjective norm variable had a positive and significant effect on the intention to quit. Judge \& Mueller (2012), suggested that the social environment such as the support of superiors or coworkers and the support of social networks can affect satisfaction at work which later satisfaction will affect the intention of employees to leave the company. The support of family and loved ones affect individuals to make a decision to keep on the current job or find a better job than before. Brouwer et al., (2009), suggested that individuals tend to act and perform suggested behaviors as expected by family, friends and direct superiors. For example, employees who feel pressured by superiors will have the intention to leave, because his family wants him to find a better job. Francis et al., (2004), states that social pressure will affect individuals in doing or not doing a behavior, in this case, the intention to quit from work.

Research by Jehanzeb et al., (2013), states that the views and thoughts of others that are significant (such as family, friends, colleagues and direct superiors) on a suggested behavior will put pressure on the individual, for example in terms of stopping work. According to Dominguez et al., (2018), also revealed that social factors involved in an individual intend to leave his job. In line with research conducted by Abrams et al., (1998), that subjective norms will be a predictor that significantly affect employees' desire to leave the organization. This is in line with the research of Dominguez et al., (2018); Hidayat \& Budiatma, (2018); Kawiana et al., (2018) and Abrams et al., (1999) that social factors are involved in an individual intending to leave his job.

Sasmita, I. A. G. D., \& Piartrini, P. S. (2019). Effect of job attitude, subjective norm and perceived behavior control on employee intention to quit. International Research Journal of Management, IT and Social Sciences, 6(5), 89-94. https://doi.org/10.21744/irjmis.v6n5.702 
The significance value of the t-test is 0.009 . The results of the analysis of the effect of perceived behavior control on the intention to quit obtained Sig. t of 0.009 with a beta coefficient of 0.298 . Sig. Value t $0.009<0.05$ indicates that $\mathrm{H} 0$ is rejected and $\mathrm{H} 1$ is accepted. This result means that perceived behavior control has a positive and significant effect on the intention to quit.

The results showed that the perceived behavior control variable had a positive and significant effect on the intention to quit. This finding is in line with research from Wu \& Chen (2014) and Verplanken et al., (2002) which suggest that behavioral control positively and significantly affect individual intention to behave. Loi et al., (2010) and Pertl et al., (2010), report that Perceived behavior control significantly affects intention to leave work. The more individuals have the confidence and ability to perform a behavior increases, the intention to quit tends to increase.

Lee et al., (2008), suggest similar things that when individuals have higher abilities and the desire to express themselves is greater then individuals will see opportunities to work in other companies and tend to have the intention to quit their jobs. Individuals are less worried about quitting their previous jobs when there are many alternatives in the labor market. Research by Foltz et al., (2016), suggests perceived behavioral control positively affect intention to behave where employees have confidence in their abilities and resources so they feel they have the opportunity to work elsewhere. This can be seen from the effect of perceived behavior control on the intention to quit, such as the financial ability of employees to pay fines as a result of quitting their jobs. The ability of employees to work in certain fields so that employees have the confidence to leave work and find better jobs and employees have the opportunity to work in other companies. This is in line with research from Yakasai (2015), which suggests that a person's behavioral intentions are strongly affected by their level of confidence in carrying out actual behavior. Ajzen (2005), states the same thing that the greater the support from the closest people and the social environment for individuals, the intention to behave will tend to increase.

\section{Conclusion}

Based on the results of the discussion of research that has been done, it can be concluded that attitude towards work has a positive and significant effect on employee intention to quit. This means that if the employee's attitude is negative towards his job, it will affect the increasing desire to leave the employee. Subjective norms have a positive and significant effect on employees' intention to quit. This means that if employees get support from family and surrounding environment factors to find a better job than their previous job, then this will affect the increasing desire to leave employees. Perceived behavior control has a positive and significant effect on employee intention to quit. This means that if employees do not have strong personal control, it will affect the increase in intention to quit.

\section{Conflict of interest statement}

The authors declared that they have no competing interest.

\section{Statement of authorship}

The authors have a responsibility for the conception and design of the study. The authors have approved the final article.

\section{Acknowledgments}

The authors would like to thank the editor of IRJMIS for their valuable time, support, and advice in completing the present research. 


\section{References}

Abrams, D., Ando, K., \& Hinkle, S. (1998). Psychological attachment to the group: Cross-cultural differences in organizational identification and subjective norms as predictors of workers' turnover intentions. Personality and Social psychology bulletin, 24(10), 1027-1039. https://doi.org/10.1177\%2F01461672982410001

Abrams, D., Hinkle, S., \& Tomlins, M. (1999). Leaving Hong Kong?: The roles of attitude, subjective norm, perceived control, social identity and relative deprivation. International Journal of Intercultural Relations, 23(2), 319-338. https://doi.org/10.1016/S0147-1767(98)00041-8

Ajzen, I. (2005). Attitudes, personality, and behavior. McGraw-Hill Education (UK).

Appollis, V. P. (2010). The relationship between intention to quit, pyschological capital and job satisfaction in the tourism industry in the Western Cape (Doctoral dissertation, University of the Western Cape).

Brouwer, S., Krol, B., Reneman, M. F., Bültmann, U., Franche, R. L., van der Klink, J. J., \& Groothoff, J. W. (2009). Behavioral determinants as predictors of return to work after long-term sickness absence: an application of the theory of planned behavior. Journal of occupational rehabilitation, 19(2), 166-174.

Clark, C. R., Doraszelski, U., \& Draganska, M. (2009). The effect of advertising on brand awareness and perceived quality: An empirical investigation using panel data. Qme, 7(2), 207-236.

DH, S. K., Rustam, A., \& Partini, P. (2007). Hubungan antara persepsi terhadap kecenderungan kepemimpinan otoriter dengan intensi turn over. Indigenous: Jurnal Ilmiah Psikologi. https://doi.org/10.23917/indigenous.v0i0.4713

Dominguez, L. C., Stassen, L., de Grave, W., Sanabria, A., Alfonso, E., \& Dolmans, D. (2018). Taking control: Is job crafting related to the intention to leave surgical training?. PloS one, 13(6), e0197276. https://doi.org/10.1371/journal.pone.0197276

Fishbein, M., Jaccard, J., Davidson, A. R., Ajzen, I., \& Loken, B. (1980). Predicting and understanding family planning behaviors. In Understanding attitudes and predicting social behavior. Prentice Hall.

Foltz, C. B., Newkirk, H. E., \& Schwager, P. H. (2016). An empirical investigation of factors that influence individual behavior toward changing social networking security settings. Journal of theoretical and applied electronic commerce research, 11(2), 1-15. https://doi.org/10.4067/S0718-18762016000200002

Francis, J., LaFond, R., Olsson, P. M., \& Schipper, K. (2004). Costs of equity and earnings attributes. The accounting review, 79(4), 967-1010. https://doi.org/10.2308/accr.2004.79.4.967

Harbison, F. H. (1973). Human resources as the wealth of nations.

Hidayat, R., \& Budiatma, J. (2018). Education and job training on employee performance. International Journal of Social Sciences and Humanities, 2(1), 171-181. https://doi.org/10.29332/ijssh.v2n1.140

Jehanzeb, K., Rasheed, A., \& Rasheed, M. F. (2013). Organizational commitment and turnover intentions: Impact of employee's training in private sector of Saudi Arabia. International Journal of Business and Management, 8(8), 79. https://doi.org/10.5539/ijbm.v8n8p79

Judge, T. A., \& Kammeyer-Mueller, J. D. (2012). Job attitudes. Annual review of psychology, 63, $341-367$. https://doi.org/10.1146/annurev-psych-120710-100511

Kawiana, I. G. P., Dewi, L. K. C., Martini, L. K. B., \& Suardana, I. B. R. (2018). The influence of organizational culture, employee satisfaction, personality, and organizational commitment towards employee performance. International Research Journal of Management, IT and Social Sciences, 5(3), 35-45.

Kim, D. J., Ferrin, D. L., \& Rao, H. R. (2003). Antecedents of consumer trust in B-to-C electronic commerce. AIS.

Korry, P. D. P., Yulianti, N. M. D. R., \& Yunita, P. I. (2017). Increase the attractiveness of local fruits to buying intention of hedonic consumers in bali. International Research Journal of Management, IT and Social Sciences, 4(6), 10-16.

Kusumanegara, I. S., Asmony, T., \& Numayanti, S. (2018). Work-family conflict on turnover intention regarding work stress as intervening variable. International Journal of Social Sciences and Humanities, 2(2), 141-154. https://doi.org/10.29332/ijssh.v2n2.153

Lee, T. H., Gerhart, B., Weller, I., \& Trevor, C. O. (2008). Understanding voluntary turnover: Path-specific job satisfaction effects and the importance of unsolicited job offers. Academy of Management Journal, 51(4), 651-671. https://doi.org/10.5465/amr.2008.33665124

Loi, R., Hang-Yue, N., \& Foley, S. (2006). Linking employees' justice perceptions to organizational commitment and intention to leave: The mediating role of perceived organizational support. Journal of Occupational and Organizational Psychology, 79(1), 101-120. https://doi.org/10.1348/096317905X39657

Mangkuprawira, S. dan AV Hubeis, 2007. Manajemen Mutu Sumber Daya Manusia. Penerbit Ghalia Indonesia, Bogor.

Sasmita, I. A. G. D., \& Piartrini, P. S. (2019). Effect of job attitude, subjective norm and perceived behavior control on employee intention to quit. International Research Journal of Management, IT and Social Sciences, 6(5), 89-94. https://doi.org/10.21744/irjmis.v6n5.702 
Martini, L. K. B., Suardana, I. B. R., \& Astawa, I. N. D. (2018). Dimension Effect of Tangibles, Reliability, Responsiveness, Assurance, Empathy, Leadership towards Employee Satisfaction. International Research Journal of Management, IT and Social Sciences, 5(2), 210-215.

Mobley, W. H. (1986). Pergantian karyawan: sebab-akibat dan pengendaliannya. Pustaka Binaman Pressindo.

Ologunde, A. O., Asaolu, T. O., \& Elumilade, D. O. (2003). Labor Turnover among University Teachers in Southwestern Nigeria-Issue, Solution and Lesson.

Pertl, M., Hevey, D., Thomas, K., Craig, A., Ní Chuinneagáin, S., \& Maher, L. (2010). Differential effects of selfefficacy and perceived control on intention to perform skin cancer-related health behaviours. Health education research, 25(5), 769-779. https://doi.org/10.1093/her/cyq031

Schalk, R., \& Van Rijckevorsel, A. (2007). Factors influencing absenteeism and intention to leave in a call centre. New Technology, Work and Employment, 22(3), 260-274. https://doi.org/10.1111/j.1468-005X.2007.00198.x

Tan, M., \& Teo, T. S. (2000). Factors influencing the adoption of Internet banking. Journal of the Association for information Systems, 1(1), 5.

Trevor, C. O. (2001). Interactions among actual ease-of-movement determinants and job satisfaction in the prediction of voluntary turnover. Academy of management journal, 44(4), 621-638. https://doi.org/10.5465/3069407

Verplanken, B., \& Holland, R. W. (2002). Motivated decision making: effects of activation and self-centrality of values on choices and behavior. Journal of personality and social psychology, 82(3), 434. https://psycnet.apa.org/doi/10.1037/0022-3514.82.3.434

Williams, E. S., Konrad, T. R., Scheckler, W. E., Pathman, D. E., Linzer, M., McMurray, J., ... \& Schwartz, M. (2000). The effects of job satisfaction and perceived stress on the physical and mental health and withdraw intentions of physicians. In Academy of Management Proceedings (Vol. 2000, No. 1, pp. C1-C6). Briarcliff Manor, NY 10510: Academy of Management.

Wu, S. I., \& Chen, Y. J. (2014). The impact of green marketing and perceived innovation on purchase intention for green products. International Journal of Marketing Studies, 6(5), 81. https://doi.org/10.5539/ijms.v6n5p81

Yakasai, A. B. M., \& Jusoh, W. J. W. (2015). Testing the Theory of Planned Behavior in determining intention to use digital coupon among university students. Procedia Economics and Finance, 31, 186-193. https://doi.org/10.1016/S2212-5671(15)01145-4

Yunita, P. I., \& Saputra, I. G. N. W. H. (2019). Millennial generation in accepting mutations: Impact on work stress and employee performance. International Journal of Social Sciences and Humanities, 3(1), 102-114. https://doi.org/10.29332/ijssh.v3n1.268 